\title{
Business model design-performance relationship under external and internal contingencies: evidence from SMEs in an emerging economy
}

Article

Accepted Version

Creative Commons: Attribution-Noncommercial-No Derivative Works 4.0

Pati, R. K., Nandakumar, M. K., Ghobadian, A., Ireland, R. D. and O'Regan, N. (2018) Business model design-performance relationship under external and internal contingencies:

evidence from SMEs in an emerging economy. Long Range Planning, 51 (5). pp. 750-769. ISSN 0024-6301 doi: https://doi.org/10.1016/j.Irp.2018.01.001 Available at https://centaur.reading.ac.uk/75893/

It is advisable to refer to the publisher's version if you intend to cite from the work. See Guidance on citing.

To link to this article DOI: http://dx.doi.org/10.1016/j.Irp.2018.01.001

Publisher: Elsevier

All outputs in CentAUR are protected by Intellectual Property Rights law, including copyright law. Copyright and IPR is retained by the creators or other copyright holders. Terms and conditions for use of this material are defined in the End User Agreement. 


\section{www.reading.ac.uk/centaur}

\section{CentAUR}

Central Archive at the University of Reading

Reading's research outputs online 


\title{
Business Model Design-Performance Relationship under External and Internal Contingencies: Evidence from SMEs in an Emerging Economy
}

\begin{abstract}
We examined Business Model (BM) designs - performance relationship and the moderating effects of firm age and external environment on this relationship. Furthermore, we investigated the impact of simultaneously operating dual BM designs (i.e. novelty and efficiency) on firm performance and contingent effect of firm age on this relationship. Based on data from 241 Indian SMEs, our findings highlighted that BM novelty was of greater benefit to younger SMEs compared to mature SMEs, while BM efficiency was of greater benefit to more mature SMEs. The environmental dynamism positively moderated the relationship between BM novelty and performance but it negatively moderated the relationship between BM efficiency and performance. We also found that BM efficiency is more beneficial in a low, rather than a high, munificent environment but we found environmental munificence did not moderate the BM novelty and SME performance relationship. Finally, we found simultaneous deployment of BM novelty and BM efficiency resulted in an enhancement of performance among mature SMEs compared to younger SMEs. Our study not only adds to the limited literature on BMs in SMEs but also helps practicing managers and entrepreneurs to make informed choices about their BMs.
\end{abstract}




\section{INTRODUCTION}

Business model (BM) designs influence firm performance (Foss \& Saebi, 2017; Zott \& Amit, 2007). Hence, the call by scholars for greater research effort directed at clarifying macro- and firmlevel factors moderating BM designs - firm performance relationship (e.g. Foss \& Saebi, 2017). Moreover, scholars have highlighted the need for improving our nascent understanding of the performance implications of simultaneously deploying several BM designs (Snihur \& Tarzijan, 2017). Finally, there is a paucity of systematic research examining the relevance of BMs in different contexts, for example, small and medium-sized enterprises (SMEs) and emerging economies (George \& Bock, 2011). This study ${ }^{1}$ addresses these recent calls by investigating the effect of internal (firm's age) and external (environmental dynamism and munificence) contingencies on BM designs - firm performance relationship. Furthermore, this study explores the performance implications of operating two different BM designs simultaneously (BM dual design) and the conditions favouring the deployment of BM dual designs using a sample of SMEs operating in an emerging economy.

The extant BM literature, despite advancing knowledge, has paid scant attention to the moderating effect of external and internal contingencies on BM designs - firm performance relationship (Foss \& Saebi, 2017; Zott et al., 2011). A firm's age is an important internal contingency factor because it influences its capabilities, strengths, and weaknesses (Carr et al., 2010), that help or hinder its ability to capture the value created by the BM design. On the other hand, a firm's external environment is a source of opportunities and challenges (Ahlstrom \& Bruton, 2006; London \& Hart, 2004) potentially impacting BM designs - firm performance

\footnotetext{
${ }^{1}$ We would like to place on the record our thanks to the two anonymous reviewers. They engaged in constructive dialogue offering insightful comments and suggestions helping us to significantly improve our manuscript.
} 
relationship. We contend that it is not possible to fully understand the BM designs - firm performance relationship without including critical contingent factors in theory development and testing. Additionally, despite the suggestion that more and more firms simultaneously deploy multiple BM designs (Casadesus-Masanell \& Tarzijan, 2012; McNamara et al., 2013; Velu \& Stiles, 2013), there is a lack of theoretical and empirical agreement as to the usefulness of simultaneously deploying dual BM design (Snihur \& Tarzijan, 2017). The primary aim of this study is to address these gaps, thus advancing theory and knowledge.

Moreover, the current BM literature is overly reliant on case studies and focused on developed economies (Battistella et al., 2017; Casadesus-Masanell \& Zhu, 2013), limiting the generalizability of the findings. Institutional voids, infrastructural limitations, and huge untapped markets at the bottom of the pyramid provide unique opportunities and challenges for firms operating in emerging economies. These differences suggest that theories and empirical findings based on firms operating in the developed economies may not fully apply to firms operating in the emerging economies (Kotha et al., 2011). Furthermore, SMEs and large firms have many differences (Deschryvere, 2014), hence, theories developed using large firms may not directly apply to SMEs. Not surprisingly many scholars have called for more systematic empirical research drawing on a broader cross-section of firms operating in different institutional frameworks to enhance the generalizability and usefulness of the BM design-performance relationship (Markides, 2013; Zott \& Amit, 2007).

To address these gaps, we initially test the impact of two archetypal BM designs (novelty and efficiency) on firm performance, but critically, we add important internal (age) and external (dynamism and munificence) contingencies to our analysis. We also examine the impact of simultaneously operating the two BM designs and moderating effect of firm age on this 
relationship. In doing so, we make a threefold contribution to the extant literature. First, we develop and extend the theory by assessing the moderating impact of age, environmental dynamism and environmental munificence on the relationship between BM designs and SME performance - showing that certain BM designs are more beneficial in some conditions than others. Second, we contribute to the BM literature by empirically examining the impact of BM dual designs on SME performance and the contingent effect of firm age on this relationship indicating that mature SMEs benefit more from BM dual design than younger SMEs. Finally, we examine the validity, generalizability, and usefulness of the BM designs using a new and unexplored context (Bettis et al., 2016) - a cross-section of SMEs operating in India.

The remainder of this study is organized as follows. The literature review and the hypotheses that explore the relationship between BM design and SME performance and the role of different contingent factors are presented in the next section. This is followed by sections on our research method; analyses and results; and discussion of the results pointing out the theoretical and managerial implications of the study. Finally, we draw our conclusions.

\section{LITERATURE REVIEW}

\section{Business Model Design}

Amit and Zott (2001) used the configuration theory to deductively identify the common design themes that orchestrate and connect the elements of a $\mathrm{BM}$; as a result, they proposed four archetypal BM design configurations - novelty, efficiency, lock-in, and complementarity. In this study, we use BM novelty and BM efficiency designs as they are closely related to important organizational concepts such as product-market strategies (Zott \& Amit, 2008); exploration and exploitation (Wei et al., 2014); technological innovation (Wei et al., 2014); and relationship marketing (Brettel et al., 2012). Moreover, lock-in and complementarity are less common, often 
restricted to high-capital industries and digital platforms, while novelty and efficiency are prevalent in all industries, influencing value creation and firm performance (Gronum et al., 2016; Kulins et al., 2016; Zott \& Amit, 2008).

Business model novelty design is anchored in Schumpeterian economics: emphasizing the introduction of new activities (content); new ways of conducting economic exchange or linking activities (structure); and new ways of governing the activities by bringing new participants on board (governance) (Amit \& Zott, 2001; Zott \& Amit, 2013). It maps closely onto explorative behaviour (Amit \& Zott, 2001; Sosna et al., 2010). In contrast, BM efficiency design is anchored in transaction-cost economics - focusing on replication and changes designed to promote transaction efficiency (Zott \& Amit, 2013). The aim is to reduce transaction costs for all transaction actors. Hence a focal firm can enhance its BM efficiency by introducing ways of doing things such as using new technology, relocating and committing to long-term contracts to increase efficiency, and reduce the transaction cost of the current content, structure, and governance (Dunford et al., 2010; Zott \& Amit, 2007). This design maps closely onto exploitative behaviour as well as capability leveraging (Amit \& Zott, 2001; Sirmon et al., 2007). Ostensibly both archetypal BM designs fit the emerging economies context with their vast untapped base-of-pyramid market.

\section{Business Model Designs and Firm Performance}

Prior studies have enriched our understanding of the BM and its evolution (DaSilva \& Trkman, 2014; Wirtz et al., 2016); its link to innovation and organizational strategy (Baden-Fuller \& Haefliger, 2013; Karimi \& Walter, 2016; Teece, 2010; Velu \& Jacob, 2016; Zott \& Amit, 2008); its role as a driver of change in industry and society (Johnson et al., 2008), and highlighted its importance for value creation, value capture, competitive advantage and firm performance (e.g. Aspara et al., 2010; Casadesus-Masanell \& Tarzijan, 2012; Velu, 2015; Zott \& Amit, 2007). The 
focus of this study is on examining BM design - firm performance; hence, we review this literature in greater detail.

Business model and its designs play a central role in explaining firm performance (Aspara et al., 2010). A suitable BM design creates a virtuous cycle that, over time, results in competitive advantage and improved performance (Casadesus-Masanell \& Ricart, 2011). In an empirical study, Zott and Amit (2007) found that two BM designs (novelty and efficiency) influenced the performance of entrepreneurial firms. Aspara et al. (2010) examined the performance difference between BM innovation and replication among large and small firms - highlighting different conditions in which firms should emphasize innovation or replication. Weill et al. (2011) concluded that BMs emphasizing intellectual property were favoured by both the stock market and investors. Ample studies have highlighted that organizations focusing on BM innovation significantly improve their performance (Cucculelli \& Bettinelli, 2015; Palmisano, 2006). Prior studies also highlight that firms replicate their success formulae and focus on established BMs to expand into new adjacent markets (Ghemawat, 2003). Replication of BMs across different markets increases their payoffs in the form of learning curve benefits, increased speed and lower complexity, and helps firms to sustain their growth (Zook \& Allen, 2003, 2011). Large firms operating in the developed economies provide the backdrop for the great majority of studies reviewed. The narrow focus of extant literature combined with the absence of studies where the backdrop is SMEs operating in emerging economies limits the generalizability of the BM designperformance relationship. Our study addresses this important anomaly.

Using contingency theory, Andries and Debackere (2007) found that constant adaptation was beneficial in less mature, capital-intensive and high-velocity industries but not so in more mature, stable industries among young technology-driven firms. Along similar lines, Demil and 
Lecocq (2010) found that a firm's sustainability and performance depends on anticipating and reacting to sequences of voluntary and emerging changes to its BM. Another study found that a firm's agility to adapt its BM helped it to withstand sudden changes in the external environment enabling it to survive and perform better in changing environmental conditions (Sull, 2009). Zott and Amit (2007) concluded that environmental munificence moderate BM design - firm performance relationship. Although recent literature has started to emphasize the importance of contingent variables, no study to the best of our knowledge explores the contingent effects of age and the environment on the BM design-firm performance relationship - especially among emerging economies SMEs.

Another important discussion revolves around the potential benefits, difficulties and consequential issues arising from operating two or more BM designs simultaneously (e.g. Kim \& Min, 2015; McNamara et al., 2013). Some scholars suggest that operating two or more BMs in parallel may result in strategic failure (Casadesus-Masanell \& Tarzijan, 2012). Introducing a new BM may cannibalize the existing BM and can threaten the existence of the business (Velu \& Stiles, 2013). Zott and Amit (2007) empirically showed that operating two different BM designs (noveltyand efficiency-driven designs) simultaneously had a detrimental impact on the performance of entrepreneurial firms.

In contrast, other scholars argue that operating a portfolio of BMs enhances firms' mediumterm viability and future development (Sabatier et al., 2010). The firms deploying BMs that attain an appropriate balance between innovation, efficiency, and customer-intimacy capabilities are likely to perform better than firms using a single BM design (Kim \& Min, 2015). Studies also indicate that if a firm is able to broaden its organizational skills, increase the flexibility of its workforce and make other investments to master more than one BM, it will be able to build 
formidable advantages that are difficult for competitors to overcome (Casadesus-Masanell \& Tarzijan, 2012). To summarize, our review suggests a lack of unanimity among scholars about the potential benefits of simultaneously operating multiple BM designs. Moreover, the previous research has paid little attention to the moderating effect of contingencies on BM dual design and firm performance. By addressing these research questions, we enhance the literature on BMs and BM dual design.

\section{HYPOTHESES}

\section{Business Model Designs and SME Performance}

\section{Business Model Novelty Design and SME Performance}

A BM novelty design enables the focal SME to introduce new activities, structure or governance. Business model novelty design creates value for the focal SMEs in emerging economies in three ways. First, it helps the focal SME to connect with new suppliers and partners who bring new resources and capabilities to the table (Dahan et al., 2010). New partners create fresh opportunities by facilitating different resource combinations (Read et al., 2009) and development of alternative superior solutions to the existing problems (Mohr \& Spekman, 2006). In emerging economies, a newly formed partnership network also helps the focal SME to manage institutional voids.

Second, BM novelty design enables the focal SME to target poorly served new customer niches by initiating new structures or links (Aspara et al., 2010). A large proportion of the population in emerging economies are located at the bottom of the pyramid with limited access to products and services (Prahalad, 2006). Business model novelty design can help SMEs to reach these untapped customers and market segments (Kim \& Mauborgne, 2005).

Third, BM novelty design supports the focal SME's effort to initiate new activities, thereby providing opportunities for vertical and horizontal growth. Moreover, adding new activities might 
increase the accessibility of the product or service enhancing convenience and customer satisfaction - increasing their willingness to pay a premium and boosting the firm's customer base as well as profitability. Hence exploring new content, structure, and governance would help SMEs in emerging economies. For example, SELCO an SME operating in the power and electricity sector in India, introduced novelty into its BM by adding rural partners for repair and maintenance and utilizing a rare and innovative financing and distribution system to provide affordable solar electricity to marginalized rural communities at the bottom of the pyramid (Pati \& Garud, 2011).

In contrast to the benefits discussed, the focal SMEs may incur all or part of the set-up costs associated with embodying novelty in the BM design. Moreover, BM novelty design might incur increased transaction costs due to coordination and trust issues as new vendors and partners enter the value chain. However, we expect the benefits of BM novelty design to outweigh the costs. Therefore, we propose the following hypothesis.

H1a: Business model novelty design has a positive effect on the performance of SMEs in emerging economies.

\section{Business Model Efficiency Design and SME Performance}

Business model efficiency design aims to improve the transparency, reliability, and accuracy of a business model - existing activities, structure, and governance (Zott \& Amit, 2010) thereby reducing the transaction cost across the value chain (Demil \& Lecocq, 2010; Zott \& Amit, 2008). Such reductions are of greater significance in emerging economies owing to the institutional void (Puffer et al., 2010). This cost advantage could help the SME to attract more customers with affordable prices and boost market share and profitability (Aspara et al., 2010). Furthermore, exploiting the existing BM along with the increase in customer base might lead to economies of scale, reducing the costs further (Schneider \& Spieth, 2013; Winter \& Szulanski, 2001). 
In emerging economies, the consumers at the bottom-of-the-pyramid are numerous with little disposable incomes, hence, they cannot afford prices paid by traditional market consumers. The focus of legacy corporation is provision of standard products /services, hence, they are not best positioned to serve the bottom-of-the-pyramid consumers and corporations are unable to serve these markets (Hart \& Prahalad, 2002; Prahalad, 2006). The cost savings offered by BM efficiency design is arguably more important to SMEs operating in emerging economies as lower prices enable them to better serve the bottom-of-the-pyramid markets. Prior studies suggest Indian SMEs that introduced technology such as inventory management system and ERP were able to keep track of retailers' inventory and orders, increasing the transparency, reliability, and accuracy of orders and deliveries (Kale et al., 2010). This helped them to save costs and increase their operational efficiency significantly (Mistry, 2005). Many Indian SMEs also relocated closer to their main market or key customer in order to reduce high logistics costs due to the poor road conditions and other institutional issues (Krishnaswamy et al., 2014). Hence exploiting the efficiency of existing content, structure, and governance benefit SMEs in emerging economies.

As in the case of BM novelty design, the focal SME might incur all or part of the set-up costs associated with embodying efficiency in BM design. Moreover SMEs, in all practical cases, are likely to have to invest in improving mutual trust and transparency among partners critical to the success of BM efficiency design. This cost would be greater for SMEs in emerging economies compared to those in developed economies because of the presence of institutional voids. However, we expect the benefits of the BM efficiency design such as cost savings and operational efficiencies to outweigh these costs in the long run. Therefore, we propose the following hypothesis.

H1b: Business model efficiency design has a positive effect on the performance of SMEs in emerging economies. 


\section{Business Model Dual Design and SME Performance}

The debate concerning the concurrent deployment of multiple BMs is attracting increasing attention. Firms like Yahoo, Intel, Ericsson, TeliaSonera, Swisscom, France Telecom, and LAN Airlines have benefited from the deployment of parallel business models (Hacklin et al., 2017; Snihur \& Tarzijan, 2017). As was pointed out earlier (see the Literature Review section) scholars are divided on the benefits of deploying two or more BMs simultaneously. We add to the literature by assessing the impact of concurrently operating dual BM designs on the performance of SMEs from emerging economies.

Business model novelty and efficiency designs are not mutually exclusive (Zott \& Amit, 2007) and hence it is possible for SMEs in the emerging economies to successfully and simultaneously pursue both archetypal designs. SMEs operating dual BM designs would incur costs associated with the complexity and coordination required for managing new partners and simultaneously building trust and transparency across all stakeholders. Once the SMEs are able to absorb these costs and adjust to these coordination mechanisms, they can benefit significantly by simultaneously exploiting the advantages of both BM novelty and efficiency. Running two parallel BMs enables firms to reduce risk significantly by diversifying their revenues and profits (Casadesus-Masanell \& Tarzijan, 2012). However, there are various challenges associated with running parallel $\mathrm{BMs}$ including failure to exploit synergies and unpredictability relating to outcomes (Markides, 2013). Parallel BMs are helpful in environments with lower degrees of value migration, which refers to the shift in the drivers of value creation between firms and their BMs (Hacklin et al., 2017). It is possible for firms to configure and manage multiple BMs either within a single business unit or in separate business units (Snihur \& Tarzijan, 2017). 
As discussed earlier, SELCO, an SME operating in the power and electricity sector in India, has a novel BM and its operation covers a comparatively small area. To take its BM novelty to other regions it needs to simultaneously design and operate an efficiency-driven BM to reduce the transaction costs, which are higher in emerging markets due to institutional voids (Puffer et al., 2010). The dual BM potentially will enable SELCO to access new untapped markets at the bottom of the pyramid, by augmenting its BM novelty with BM efficiency, reducing transaction costs, and managing institutional and infrastructural voids better. Hence, we propose the following hypothesis.

H1c: Business model dual design is positively associated with the performance of SMEs in emerging economies.

\section{Business Model and SME Performance: Moderating Effect of Age}

We use contingency theory to theorize that the relationship between BM design and SME performance is critically dependent on the internal and external contingent factors. A number of scholars have highlighted the importance and relevance of the internal environment, characterized by capability and its moderating influence on firm performance (Lepak et al., 2007). In this study, we use the SME's age to operationalize the internal environment and examine its moderating effect on the BM design-SME performance relationship. An SME's age can be an important determinant of its resources (Autio et al., 2000) and internal capabilities (Sapienza et al., 2006; Thornhill \& Amit, 2003). Both young and established SMEs have their own sets of resources and capabilities depending on their age, which provides both strengths and liabilities (Carr et al., 2010). These strengths and liabilities influence the ability of SMEs to capture the value created by their BM design and can help or limit the impact of BM design on SME performance. Moreover, age can be measured objectively. Our conceptual model is presented in Figure 1. 
[Insert Figure 1 about here]

\section{Business Model Novelty Design and SME Performance: Impact of Age}

Business model novelty design creates value for SMEs operating in emerging economies by developing new capabilities and creating fresh opportunities for growth (Chesbrough, 2010). Although all SMEs gain from BM novelty design, those that are more flexible and adaptive are likely to benefit more. Younger SMEs have a strong exploratory acumen, less complex decisionmaking mechanisms, nimble processes and flexible structure as compared to mature SMEs (Thornhill \& Amit, 2003). Hence younger SMEs are more adaptive and potentially benefit more from innovation than mature SMEs (Zhou \& Wu, 2009). Moreover, compared to mature SMEs, younger SMEs generally have clear and informal communication channels and encourage creativity among their employees (Zaheer \& Bell, 2005). These characteristics suggest that younger SMEs are better positioned to take advantage of the opportunities created by BM novelty design than mature SMEs. Rosenbusch et al. (2011), in their meta-analysis, also found that younger firms captured more value from innovation-related opportunities than mature firms. Therefore, we propose the following hypothesis.

H2a: Business model novelty design has a higher positive effect on the performance of younger SMEs than on mature SMEs in emerging economies.

\section{Business Model Efficiency Design and SME Performance: Impact of Age}

Business model efficiency design creates value by reducing cost, eliminating slack, developing scale and making transactions more transparent, reliable and accurate (Zott \& Amit, 2010). To fully reap the benefits of efficiency and cost savings, emerging economy SMEs need to develop disciplined learning methods, stable processes and long-term partnerships (Kotha et al., 2011). Moreover, effective BM efficiency design depends on trust among partners. Over time, mature 
SMEs learn from their experiences, and develop stable processes and established routines that could help them develop long-term partnerships and capture more value from efficiency than younger SMEs (Kotha et al., 2011). With time, mature SMEs develop an in-depth understanding of their domains and trust among their partners (Zahra \& George, 2002). Hence mature SMEs benefit more from established content, structure, and governance mechanisms than younger SMEs in emerging economies. Therefore, we propose the following hypothesis.

H2b: Business model efficiency design has a higher positive effect on the performance of mature SMEs than on younger SMEs in emerging economies.

\section{Business Model Dual Design and SME Performance: Impact of Age}

Simultaneous deployment of novelty- and efficiency-driven BM designs may create substantial long-term value if a firm learns and masters the capabilities and coordination mechanisms required to operate the two BM designs side by side. However, if the SME is unable to manage the cost and coordination mechanisms associated with BM dual design it generates significant tension, leading to the failure of both BMs and a decrease in SME performance (Lavie et al., 2011; Markides, 2013). Hence employing multiple BMs simultaneously is challenging and carries a risk of failure

(Winterhalter et al., 2016). Successful BM dual design is aided by firms' ability to employ temporal, contextual and domain separation between its BMs (Markides, 2013).

Prior studies have highlighted that a firm's capabilities and resources determine its ability to successfully operate multiple BMs simultaneously (Casadesus-Masanell \& Tarzijan, 2012; Mezger, 2014). In emerging economies, mature SMEs have greater experience, more resources, broader organizational skills, trust within their network of partners and stronger informal networks in comparison to younger SMEs (Zahra \& Filatotchev, 2004). Hence, we theorize that the experience and organizational skills of mature SMEs make it easier for them to employ temporal, 
contextual and domain separation, enabling them to successfully resolve the tensions inherent in BM dual design as compared to younger SMEs in emerging economies. Therefore, we propose the following hypothesis.

\section{H2c: Business model dual design has a higher positive effect on the performance of mature SMEs than on younger SMEs in emerging economies.}

\section{Business Model Design and SME Performance: Moderating Role of the Environment}

External environmental factors are beyond the control of firms, yet they are omnipresent, exerting significant influence on firms' performance (Shrader et al., 1984). The environment holds great challenges for and offers new opportunities to SMEs(Ahlstrom \& Bruton, 2006; London \& Hart, 2004). The impact of the environment is more pronounced in emerging than developed economies simply because their weak institutions tend to behave in an unpredictable ad hoc manner creating uncertainty and a random operating environment, hence generating added strain for SMEs (Puffer et al., 2010). These challenges and opportunities affect BM design - firm performance relationship (Zott \& Amit, 2007). Extending these arguments, we theorize that an emerging economy's SME operating environment moderate BM design - SME performance relationship.

Prior studies have classified the operating environment into three clusters: dynamic, munificent and complex (Dess \& Beard, 1984). These classifications are predicated on two critical dimensions - intangible and tangible (Lumpkin \& Dess, 2001). The intangible dimension characterizes the environment as a source of information, while the tangible dimension characterizes the environment as a source of resources. Dynamic and complex categories are closely associated with signals emanating from the operating environment (information) - that is the degree of uncertainty faced by an SME - and munificence is an indicator of the richness or paucity of resources available to an SME. In exploring the environment's contingent impact, many 
prior empirical studies have relied on dynamism and munificence because they are orthogonal and indicate two separate, yet important, dimensions of the environment (e.g. Goll \& Rasheed, 2004; Siqueira et al., 2016). Moreover, the extant literature suggests that the two most appropriate environmental dimensions for assessing the effectiveness of BMs are the levels of munificence and dynamism (Sanchez \& Ricart, 2010). Therefore, we use dynamism and munificence as moderators for BM design-SME performance in this study.

A dynamic environment is characterized by a high rate of change and a high degree of instability, which increases the level of uncertainty for SMEs (Green et al., 2008). In highly dynamic environments SMEs need to grasp opportunities quickly before their worth is diminished (Li \& Liu, 2014). In contrast, environments with low levels of dynamism bring stable opportunities, which require long-term commitment and partnership. Consistent with prior learning, in low-dynamic environments, search processes for new ideas are slow and infrequent (Nelson \& Winter, 1982). In environments with low levels of dynamism, changes in existing capabilities and core competencies are infrequent and incremental (Volberda, 1996). Munificence describes the availability of critical resources that are needed by a firm for its survival and growth (Castrogiovanni, 1991; Green et al., 2008). A high level of munificence in the environment is characterized by resource abundance, low competition and the availability of multiple new opportunities. In contrast, low levels of munificence in the environment indicate resource scarcity, intense regulatory burdens, a high level of competition or a paucity of new opportunities (Brouthers et al., 1996). Both high and low levels of dynamism and munificence in the environment bring opportunities and challenges (Lumpkin \& Dess, 2001) and contingency theory suggests that SMEs that align their BM design with their environments are more likely to survive 
and prosper (Covin \& Slevin, 1989). Therefore, both dynamism and munificence in the environment would moderate the relationship between BM design and SME performance.

\section{Business Model Novelty Design and SME Performance: Impact of Dynamism}

Business model novelty design helps SMEs create and capture value by quickly adapting their current activities, ways of coordination and exchange, and bringing new participants on board (Zott \& Amit, 2013). Hence by making it possible to swiftly introduce new activities and develop effective links between governance mechanisms, BM novelty design offers a better alignment with environments where the rate of change is rapid or there is instability. In highly dynamic environments the levels of uncertainty, instability, and rate of change are high (Li \& Simerly, 1998), providing opportunities that have to be captured quickly by the SMEs before the environment changes and the opportunity loses its value (Li \& Liu, 2014). The institutional and infrastructural voids of emerging economies increase the uncertainty inherent in a dynamic environment putting greater pressure on the SMEs operating in such environments to adapt more rapidly to take advantage of such time-bound opportunities. To capture such opportunities and manage the challenges, SMEs have to adapt quickly and frequently (Ensley et al., 2006; Green et al., 2008). Business model novelty design helps SMEs to effectively capture such time-bound opportunities and avoid the threats due to high dynamism in the environment. In contrast, lowdynamic environments bring opportunities that require long-term commitment and partnerships. These opportunities encourage SMEs to have a stable business model without a continuous change in existing activities and partnership - limiting the ability of SMEs to implement BM novelty effectively. Moreover, SMEs and their potential partners operating in highly dynamic environments have to make quick decisions often based on incomplete information (Miller, 2007). Highly dynamic environments also provide firms with an opportunity to convince stakeholders 
about the merits of change, as potential partners are more flexible and open to change in highly dynamic environments compared to environments with low levels of dynamism (Wernerfelt \& Karnani, 2006). This reduces the initial governance cost (i.e. the cost of convincing partners) for BM novelty. Therefore, we propose the following hypothesis.

H3a: Business model novelty design has a higher positive effect on the performance of SMEs operating in environments with high levels of dynamism compared to those operating in environments with low levels of dynamism in emerging economies.

\section{Business Model Novelty Design and SME Performance: Impact of Munificence}

Business model novelty design positively influences firm performance by introducing new suppliers and partners who bring new resources and capabilities to the table (Dahan et al., 2010). The opportunity to introduce new activities and means of transaction enhances SMEs' growth prospects. However, these novel additions require substantial investments. SMEs operating in environments with high levels of munificence have access to adequate resources, while SMEs operating in low-munificence environments face severe resource constraints (Brouthers et al., 1996). High levels of munificence in the environment also provide enough slack resources, when compared to low levels of environmental munificence, to initiate new activities, try new structural sequencing and invest in complementary assets that could support and implement BM novelty and innovation (Zott \& Amit, 2007). Moreover, highly munificent environments enable SMEs to reduce their dynamic governance costs, such as persuasion, negotiation and coordination costs (Langlois \& Robertson, 1995; Zott \& Amit, 2007) as compared to environments with low levels of munificence. In contrast, SMEs operating in environments with low levels of munificence find it more difficult to generate slack resources or devote sufficient managerial attention to exploit new opportunities generated by BM novelty design. Additionally, low levels of munificence lead to severe competition within the industry - reducing the bargaining power of SMEs over others 
and thereby reducing their ability to appropriate maximum value creation offered BM novelty (Zott \& Amit, 2007). Therefore, we propose the following hypothesis.

H3b: Business model novelty design has a higher positive effect on the performance of SMEs operating in environments with high levels of munificence compared to those operating in environments with low levels of munificence in emerging economies.

\section{Business Model Efficiency Design and Firm Performance: Impact of Dynamism}

Business model efficiency creates value by making transactions more reliable and accurate, reducing transaction costs and encouraging SMEs to replicate their BM elements (i.e. content, structure, and governance) over a period of time - leading to greater learning and exploitation of economies of scale (Winter \& Szulanski, 2001). Therefore, BM efficiency design is best suited to exploit opportunities that require long-term partnerships, stable transactional relationships, and trust among partners. A low level of dynamism provides SMEs with the opportunity to exploit their capabilities taking full advantage of openings offered by such environments (Li \& Liu, 2014). The minimal changes in the existing market segments, typical of low-level dynamism (Gersick, 1991), enable SMEs to increase the value created by BM efficiency. Environments with low levels of dynamism also provide SMEs ample time to evaluate and pursue the opportunities that align with BM efficiency design - leading to a higher impact of BM efficiency on SME performance. Therefore, BM efficiency design is more effective in environments with low levels of dynamism that support a stable BM rather than frequent changes in the BM. Moreover, BM efficiency design fits the demands of low dynamic environments as it provides greater opportunity to exploit established routines and operational capability. In contrast, highly dynamic environments bring opportunities that require quick action and flexibility in the BM. Pursuing such opportunities using BM efficiency limits the impact of BM efficiency on SME performance. Institutions reduce uncertainty in transactions and in emerging economies, where institutions are underdeveloped, 
transactions incur higher costs due to institutional voids (Puffer et al., 2010) limiting the impact of BM efficiency on firm performance. Moreover, the sunk costs of establishing BM efficiency design are high due to the reliance on long-term commitment (Zott \& Amit, 2007). In highly dynamic environments, it is difficult to fully amortize this sunken cost (Siqueira et al., 2016) because SMEs need to vary their value proposition or market segments. Hence in dynamic environments the ability of SMEs to either fully reap the benefits of a BM efficiency design, or gain sufficient return on the initial investment, is limited. Therefore, we propose the following hypothesis.

H3c: Business model efficiency design has a higher positive effect on the performance of SMEs operating in environments with low levels of dynamism compared to those operating in environments with high levels of dynamism in emerging economies.

\section{Business Model Efficiency Design and Firm Performance: Impact of Munificence}

As discussed earlier, BM efficiency design reduces the overall transaction cost and increases the simplicity, reliability, and accuracy of transactions (Amit \& Zott, 2001). A low-munificence environment is characterized by scarcity of resources and a high level of competition for resources (Zahra \& Covin, 1995). Precarious industry settings, intense competition, harsh business climates and a relative lack of exploitable opportunities limit the prospects of SMEs to engage in explorative activities (Covin \& Slevin, 1989). The opportunities to develop new products are limited due to the paucity of slack resources in low-munificence environments. SMEs are unlikely to experiment and take calculated risks - focusing on servicing existing niches more efficiently. In such difficult environmental conditions, BM efficiency design helps an SME to exploit its latent values by focusing on improving the efficiency of its existing activities, their sequencing, and governance. This leads to transaction reliability, accuracy and reduced coordination costs (Amit \& Zott, 2001; Zott \& Amit, 2007), which may matter less in highly munificent environments. Moreover, the 
competitive pressures in low-munificence environments are high - and hence customers expect a low price for goods and services. In such cases, BM efficiency design allows for more efficient scaling, reducing the final cost to the customer, thereby retaining existing customers and even attracting new ones. In contrast, munificent environments provide access to more lucrative opportunities and revenue streams for SMEs other than cost cutting (Aragon-Correa \& Sharma, 2003). Therefore, we propose the following hypothesis.

H3d: Business model efficiency design has a higher positive effect on the performance of SMEs operating in environments with low levels of munificence compared to those operating in environments with high levels of munificence in emerging economies.

\section{RESEARCH METHOD}

In this section, we describe the sample, the data collection, the study's variables and their operationalization. We also explain our strategies for addressing potential biases in our sample.

\section{Sample and Data Collection}

In order to test the proposed hypotheses, we collected data from owner-managers of SMEs in India. We chose Indian SMEs because India is one of the most significant emerging economies with institutional voids and a vast untapped market at the bottom of the pyramid. Moreover, the importance of SMEs, especially in an emerging economy, cannot be ignored as they account for the majority of firms and thereby drive the economy (Lukács, 2005). As in other emerging economies, SMEs in India contribute not only in terms of output, employment, income, investment, and exports, but they also help to create balanced regional growth, nurture entrepreneurial spirit, encourage innovation, drive efficiency, and develop a wide pool of skilled and trained staff (Ayyagari et al., 2007; Terziovski, 2010). 
We took utmost care while designing the instrument and conducting the data collection to minimize biases. In order to ensure that the data are collected from the entrepreneurs and ownermanagers of SMEs rather than other employees, a hand-delivered survey questionnaire was distributed only to entrepreneurs and owner-managers who attended various short- and long-term training programmes, small business conferences, and trade meetings. The respondents were provided with an option to keep their responses anonymous (Podsakoff et al., 2003) and drop their completed questionnaires in a box kept in a communal area. This practice was helpful in obtaining honest responses, increasing the response rate and minimizing response biases due to social desirability.

To ensure consistency, the survey contained a basic definition of BM novelty and BM efficiency designs. We handed our questionnaire to 410 entrepreneurs and owner-managers and received 308 completed responses. The responses were checked for compliance with the size and operating age criteria as well as completeness of response. As a consequence, we discarded four responses because the respondent's firm violated size criterion, that is, employed more than 500 people. Our definition of SME is in line with that used in prior studies conducted in India and internationally (Javalgi \& Todd, 2011; O'Regan \& Ghobadian, 2004). Furthermore, we excluded partially completed responses and responses from firms in existence for less than two years to avoid including unstable and underdeveloped BMs in our analysis. This led to the removal of another 63 responses. Following the initial scrutiny, we were left with 241 usable responses.

\section{Dependent Variable}

The dependent variable in this study is firm performance. Due to the limited availability of data in the public domain on the performance of Indian SMEs, our study uses self-reported performance measures by respondents - entrepreneurs and owner-managers. The respondents were asked to 
indicate the extent to which their revenue, profit, sales growth, the growth of profit after tax, market share, competitive position and overall performance have either deteriorated or improved in comparison to their main competitors in the last three years. This seven-item scale $(\alpha=0.914)$ was adapted from Ramanujam and Venkatraman (1987). Many recent studies have also used the similar measurement of performance (see Gupta \& Batra, 2016; Nandakumar et al., 2010).

We also requested the respondents to provide the actual return on assets (ROA) figures for three financial years prior to the year of data collection; 64 SMEs provided these values. We found average ROA for the last three years highly correlated $(r=0.615, \mathrm{p}<0.001)$ with the relative competitive performance measures reported by the respondents. Hence there is a high degree of confidence in the robustness of the performance measures used in this study.

\section{Independent Variables}

Business model novelty and BM efficiency designs are the two independent variables used in this study. To measure BM novelty and BM efficiency we used seven-item $(\alpha=0.876)$ and nine-item $(\alpha=0.894)$ scales respectively, which were adapted from Zott and Amit (2007). The respondents were asked to indicate the extent to which they agreed or disagreed with the statements relating to the novelty and efficiency design of their SME's BM. The final items of the scales used in this study are presented in Appendix I.

\section{Moderating Variables}

The age of the firm is used as a moderating variable in this study. We considered SMEs that have been in existence for more than ten years as mature and established and we coded them as 1 , and SMEs in existence for less than ten years as young and coded them as 0 . This approach to categorization is widely used in previous studies (Yli-Renko et al., 2001). In the final sample, 
$35.7 \%$ of the SMEs were young and $64.3 \%$ were mature and established SMEs. To check the robustness of the study, we repeated the analyses by considering mature and established firms as those in existence for more than seven years and found the results of the hypotheses to be consistent.

Environmental dynamism and munificence are also used as moderating variables in this study. To measure dynamism, we adapted the scale used by Miller and Friesen (1982). The respondents were asked to indicate their level of agreement or disagreement with various statements relating to the dynamism of the external environment. All the items in the scale were reverse coded (high scores indicate low dynamism) and we coded it again so that high scores reflected high levels of dynamism. The final scale of dynamism had five items with a good reliability score of $0.737(\alpha=0.737)$. To measure munificence, we adapted the scale used by Slevin and Covin (1997). The respondents were asked to indicate their level of agreement or disagreement with the statements relating to the munificence of their operating environment. All the items in the scale were reverse coded (high scores indicate low munificence) and we coded it again so that high scores reflected high levels of munificence. The final scale of munificence had four items with the reliability score of $0.745(\alpha=0.745)$. This is a widely used scale to measure munificence in the external environment (Green et al., 2008). The final items of the scales used in the study are presented in Appendix I.

\section{Control Variables}

Firm size, international exposure and industry sector are used as control variables in this study as they might influence firm performance. The inclusion of these control variables is helpful in ensuring the consistency of estimates (Antonakis et al., 2010). Ample studies have highlighted the impact of firm size on performance, and hence we have included it as a control variable (Husted 
\& Allen, 2007). Firm size is included as a scale variable from 1 to 5 , where each number is scaled up to 100 employees. That means 1 represents SMEs with less than 100 employees, 2 represents SMEs with a number of employees from 100 to 200 , and so on. In our final sample, $82.6 \%$ of SMEs had less than 100 employees, $8.3 \%$ had 100 to 200 employees, 3.7\% had 200 to 300 employees, 3.3\% had 300 to 400 employees and $2.1 \%$ had 400 to 500 employees. Prior studies have highlighted the importance of internationalization and its impact on firm performance (Zahra et al., 2000). Therefore, we have included the presence of an international office as a control variable. SMEs with an international office are coded as 0 while SMEs with no international office were coded as 1 . In our sample, only $17 \%$ of the SMEs have international offices and have operations in a country other than India. The extant literature suggests that industry sector influences a firm's processes and its performance (Habib \& Victor, 2006). In our study, we controlled for industry sector by including it as a dummy variable and coded the dummy variable as 0 for service-based SMEs and 1 for manufacturing SMEs. In our sample, 39.3\% were servicebased SMEs and $60.7 \%$ were manufacturing SMEs.

\section{Addressing potential biases in sample}

We took adequate measures to minimize potential biases. In order to minimize single response bias or key informant bias, we asked 72 SMEs that had voluntarily provided their contact details to ask a partner or a senior executive to complete the survey. We received completed questionnaires from 32 out of the 72 SMEs. Intra-class correlation coefficients (ICC) for BM novelty (ICC $=0.85, \mathrm{p}<0.001$ ), BM efficiency (ICC $=0.89, \mathrm{p}<0.001)$ and firm performance (ICC $=0.91, \mathrm{p}<0.001$ ) indicate high inter-rater reliability (Bliese, 1998), suggesting that key informants provided reliable information. Then, to check for systematic bias in completed responses, we compared the partially completed responses to the fully completed responses. Multivariate t-tests 
showed no significant difference between completed and incomplete responses, suggesting a limited influence of systematic bias in our sample.

Although self-selected samples are not unusual in business and management research (Bono \& McNamara, 2011; Kotha et al., 2011), we further attempted to mitigate possible effects of self-selection by following a three-step procedure. First, we collected our data at the commencement of the training programmes reducing the potential impact of the training on participants' responses. Second, we collected an additional 43 useable responses from ownermanagers of Indian SMEs who did not attend any meetings, conferences or programmes. We found no significant differences in the demographics and response patterns of the attendees (our sample) and non-attendees (43 additional responses) indicating limited self-selection bias influencing our results. Third, we also compared the demographics of the sample with the population census provided by the Development Commissioner, Ministry of Micro, Small and Medium Enterprises, Government of India ${ }^{2}$ and found them to be similar. For example, 93\% of the SMEs in our sample were proprietary owned compared to $90.8 \%$ of Indian SMEs classified as proprietary owned. In terms of gender, $10.5 \%$ of SMEs in our sample had woman owners compared with $13.7 \%$ woman owners among the population of Indian SMEs. About $60.70 \%$ and $39.30 \%$ of SMEs in our sample operate in the manufacturing and service industries, respectively, compared to $67.10 \%$ and $32.90 \%$ of Indian SMEs population operating in manufacturing and service industries, respectively. These suggest that our sample is broadly representative of the population of Indian SMEs and very similar to the distribution found by other researchers using random sampling techniques (e.g. Javalgi \& Todd, 2011).

\footnotetext{
${ }^{2}$ Fourth All India Census of Micro, Small and Medium Enterprises 2006-2007: Registered sector (http://www.dcmsme.gov.in/publications/FinalReport010711.pdf)
} 
Moreover, in administering and designing the survey we took a number of steps to address common method variance (CMV), taking our lead from Podsakoff et al. (2003), MacKenzie and Podsakoff (2012) and Craighead et al. (2011). First, we selected respondents with sufficient knowledge to properly address each measure. Second, we obtained additional responses from 32 additional respondents among our sample of SMEs and compared these with responses by the first respondents for bias. As indicated, the inter-rater reliability was high. Third, we protected respondents' anonymity. Fourth, as far as possible we ordered questions to disrupt potential inference between questions. Fifth, and most importantly, respondents completed filler tasks (additional unrelated questions) to create psychological separation between measurements of dependent and independent variables.

We carried out a number of tests to determine whether or not CMV was present. First, we carried out one-factor analysis proposed by Harman (1976). This revealed the presence of five factors explaining $59.28 \%$ of the total variance and the first (largest) factor explained $15.80 \%$ of the variance, indicating no major issues due to CMV. Second, following Podsakoff et al. (2003), we found that path coefficients of the core model including BM novelty, BM efficiency and firm performance remained essentially the same after integration of an idle latent factor (model without common method factor: $\left(\chi^{2} / \mathrm{df}=1.45, \mathrm{CFI}=0.962, \mathrm{RMSEA}=0.043, \mathrm{TLI}=0.958\right)$; model with common method factor: $\left.\left(\chi^{2} / \mathrm{df}=1.46, \mathrm{CFI}=0.965, \mathrm{RMSEA}=0.044, \mathrm{TLI}=0.957\right)\right)$. Finally, we followed Lindell and Whitney (2001) and included 'interdepartmental coordination', as a marker variable in the questionnaire to check whether common method bias could have an impact on the results. The marker variable was unrelated to the dependent (SME performance) variable $(\mathrm{r}=-$ 0.02 , ns) and partial correlations between all hypothesized variables remained statistically significant while controlling for the marker variable (Johnson \& Hall, 2005; Williams et al., 2010). 
Overall, these results suggest little threat from CMV and provide support for the validity of our measures.

Furthermore, following Landis and Dunlap (2000), we set BM novelty and BM efficiency as the dependent variables to test the interaction effects of firm performance and moderating variables ('environmental munificent' and 'environmental dynamism'). Since none of these reverse interaction terms are significant, we conclude that reverse causality is of minimal concern in our data.

\section{ANALYSES AND RESULTS}

Table 1 presents descriptive statistics and zero-order correlations among all variables used in the regression analyses. All correlations are below 0.5 , suggesting that multicollinearity issues are unlikely (Tabachnick \& Fidell, 2012). The maximum value of the variance inflation factor (VIF) was well below the acceptance limit of 10 , further reducing concerns about multicollinearity.

[Insert Tables 1 and 2 about here]

Table 2 reports the results of the hierarchical regression analyses conducted to test our hypothesis. SME performance was entered into the regression model as the dependent variable in all the models - Model 1 to Model 6. We entered all the control variables in Model 1 and found SME size $(\beta=0.265, \mathrm{p}<0.001)$ to have a significant positive correlation with SME performance. Then we added the main effects of independent variables and moderating variables in Model 2. As expected, BM novelty $(\beta=0.314, \mathrm{p}<0.001)$ was significantly and positively related to SME performance. Thus, Hypothesis 1a was supported. However, in contrast to our expectation, there was no significant relationship between the main effect of BM efficiency and SME performance indicating no support for our Hypothesis 1b. Model 3 to Model 6 were created by adding mean 
centred interaction terms. The interaction term of BM novelty and BM efficiency is added in Model 3. Although we found a positive coefficient of this interaction term it was not significant, indicating that our Hypothesis $1 \mathrm{c}$ is also not supported. Then we included the interaction term between SME age and archetypal BM designs in Model 4. We found the interaction term between SME age with BM novelty to be negatively correlated $(\beta=-0.250, p<0.01)$ and the interaction term between SME age and BM efficiency to be positively correlated $(\beta=0.601, p<0.001)$ to SME performance indicating support for our Hypothesis $2 \mathrm{a}$ and Hypothesis $2 \mathrm{~b}$ respectively. We also found a positive association between the three-way interaction term $(\mathrm{BM}$ novelty $\times \mathrm{BM}$ efficiency $\times$ SME age $)$ and SME performance $(\beta=0.257, \mathrm{p}<0.01)$ when it was added in Model 5 . Thus, our Hypothesis 2c is supported. Finally, Model 6 reports the moderating effects of environmental dynamism and munificence on archetypal BM design and SME performance. Our findings indicate that the interaction between BM novelty and dynamism is significantly positive $(\beta=0.152, p<0.05)$, but the interaction between BM novelty and munificence is non-significant. Therefore, our Hypothesis 3a is supported but Hypothesis $3 \mathrm{~b}$ is not supported. We also found that the interaction between BM efficiency and dynamism $(\beta=-0.148, \mathrm{p}<0.05)$ and interaction between $\mathrm{BM}$ efficiency and munificence $(\beta=-0.210, \mathrm{p}<0.05)$, has a significant negative association with SME performance. Thus, both Hypothesis 3c and Hypothesis 3d are supported. Effect sizes of Model 1, Model 2 and Model 3 were medium with the Cohen $\mathrm{f}^{2}$ as $0.09,0.23$ and 0.24 respectively. Model 4, Model 5 and Model 6 were found to have high effect size with Cohen $\mathrm{f}^{2}$ as $0.47,0.51$ and 0.62 respectively. In order to facilitate the interpretation of the results, we present plots of the interaction terms as recommended by Cohen et al. (2013) (see Figures 2 to 7).

[Insert Figures 2 to 7 about here] 


\section{Additional Analysis}

We conducted additional checks to substantiate the robustness of our findings. First, we used the ROA from 64 SMEs as an alternate dependent variable. We found the ROA of these 64 SMEs highly correlated $(\mathrm{r}=0.615, \mathrm{p}<0.001)$ with their relative competitive performance measures, hence providing a high degree of confidence in the robustness of the performance measures used in this study. Then we used subgroup analysis and checked the correlation between dependent variables and ROA across high and low levels of moderators. We used median split to generate subgroups for environmental munificence and dynamism. The nature and direction of the results were consistent with our main findings. These results are provided in Table 3.

[Insert Table 3 about here]

The findings highlighted that for the sample of all SMEs, BM novelty $(r=0.620, p<0.01)$ and BM efficiency $(r=0.420, p<0.01)$ are significantly correlated to ROA. However, their interaction was not found to be significant. Both mature and younger SMEs benefited from BM novelty; however, the correlation between BM novelty and ROA was higher for younger SMEs ( $\mathrm{r}$ $=0.699, \mathrm{p}<0.01)$ than mature SMEs $(\mathrm{r}=0.535, \mathrm{p}<0.01)$. We also found that BM efficiency is highly correlated to ROA among mature SMEs $(r=0.686, p<0.01)$ but not among the younger SMEs. The finding also highlighted that interaction between BM novelty and BM efficiency is negatively correlated to ROA of younger SMEs $(r=-0.494, p<0.05)$. The correlation between BM novelty and ROA were similar in environments with high and low levels of munificence; but the correlation was higher in environments with high level of dynamism $(r=0.709, p<0.01)$ than in environments with low levels of dynamism $(\mathrm{r}=0.561, \mathrm{p}<0.01)$. The correlation between $\mathrm{BM}$ efficiency and ROA was found to be significant in environments with low levels of munificence 
$(\mathrm{r}=0.563, \mathrm{p}<0.01)$ and low levels of dynamism $(\mathrm{r}=0.547, \mathrm{p}<0.01)$ but were not found to be significant in environments with high levels of munificence and high levels of dynamism.

Second, to explore the relationship between the interaction effect of BM novelty and BM efficiency on SME performance, we analysed performance differences across four subgroups generated by using median split for BM novelty and BM efficiency. We found no significant differences across means $(\mu)$ of performance when SMEs focus on the following: high BM novelty and low BM efficiency (subsample 1: $\mu=4.813$ ); high BM efficiency and low BM novelty (subsample 2: $\mu=4.742$ ); high BM novelty and high BM efficiency (subsample 3: $\mu=4.818$ ). However, we found significantly lower performance for SMEs that place emphasis neither on BM novelty nor on BM efficiency (i.e. low BM novelty and low BM efficiency; subsample 4: $\mu=$ 4.011), indicating clearly that BM designs not based on BM novelty or BM efficiency are less effective among SMEs in emerging economies. Furthermore, we split subsample 3 (i.e. high BM novelty and high BM efficiency) across SME age and found the mean of performance for mature SMEs $(\mu=5.15)$ to be significantly higher than younger SMEs $(\mu=3.93)$. This again reinforces our finding that mature SMEs benefit more by emphasizing BM novelty and BM efficiency simultaneously, than younger SMEs.

Third, we estimated non-linear effects of BM novelty and BM efficiency on SME performance by adding their quadratic term along with the linear term to the regression model. Since the quadratic terms of both BM novelty and BM efficiency were not significantly related to SME performance, we concluded that non-linear effects are not present in our data.

Finally, following Landis and Dunlap (2000), we tested for reverse causality within our data. We set BM novelty and BM efficiency as dependent variables and SME performance as an independent variable. Then we tested the interaction effects of the moderating variables 
(environmental dynamism and munificence) on this relationship and found none of these reverse interaction terms were significant. Therefore, we conclude that reverse causality is of minimal concern in our data.

In summary, we found that BM novelty positively influences the performance of all SMEs; however, BM efficiency did not have a significant direct effect on SME performance. We also found that: (1) BM novelty design benefited younger SMEs more than mature SMEs, and (2) BM efficiency design benefited mature SMEs more than younger SMEs. Exploring the contingent effect of the external environment, we found: (1) BM novelty provided greater performance benefits when the environmental dynamism was high compared to when it was low; (2) BM efficiency was more effective in environments with low dynamism than those with high dynamism; (3) high environmental munificence did not influence the relationship between BM novelty and SME performance; but (4) BM efficiency had a greater positive influence on SME performance when the environmental munificence was low compared to when it was high. It was interesting to note that $\mathrm{BM}$ duality design was more effective in the case of mature SMEs than younger SMEs. These findings enable SMEs to better understand the relationship between BM designs and their performance - helping them to address misalignments when necessary. The results obtained by testing our hypotheses are summarized in Table 4.

[Insert Table 4 about here]

\section{DISCUSSION AND CONCLUSION}

We add to the BM literature by developing a set of hypothesis showing the moderating influence of internal (firm age) and external environment (dynamism and munificence) contingencies on the BM design - SME performance relationship and empirically testing our hypothesis. Furthermore, we develop hypothesis describing the relationship between simultaneous deployment of dual BM 
designs and firm performance, empirically test our hypothesis showing where operating dual design is likely to produce positive outcome using a large-scale data set. Finally, we enhance theoretical viability, generalizability, and usability of BM design - firm performance relationship by using an understudied context - a sample of SMEs operating in an emerging economy - to examine this relationship. In this section, we discuss and highlight how our research contributes to and advances the BM literature.

First, we explore the direct and interaction effect of BM novelty and BM efficiency designs on the performance of SMEs operating in emerging economies. In common with Zott and Amit (2007), we found BM novelty design had a positive impact on SME performance but the relationship between BM efficiency design and SME performance was weak and inconsistent. The benefits of BM efficiency design depend on cost savings arising from the transparency and reliability of the transaction. Lack of mutual trust among partners may partially account for this finding. It is also possible that the recovery of initial costs associated with implementing BM efficiency design and the benefits flowing from it in the form of cost savings are context dependent. We found that BM dual design did not influence SME performance. This is in line with Zott and Amit's (2007) findings - with one important difference. Although the findings were nonsignificant at the 5\% level, coefficient sign was positive and at odds with Zott and Amit (2007) who found the sign to be negative. One possible explanation for this difference is the sample age. Our sample was skewed towards mature SMEs, while Zott and Amit (2007) drew their sample from among young entrepreneurial firms. We also found a negative sign when considering only young SMEs in our sample. This suggests the importance of firm age.

In terms of novel contributions to the literature, we examined the contingent effect of firm age on the relationship between BM design and SME performance. Although a positive 
relationship between BM novelty design and SME performance was found across all firms, we found that younger SMEs benefit more from BM novelty design than mature SMEs. This finding is consistent with prior literature on the innovation-performance relationship. Rosenbusch et al. (2011) conducted a meta-analysis of 42 empirical studies encompassing 21,270 firms and concluded that younger firms benefit more from innovation than mature firms. We also found that mature SMEs benefit more from BM efficiency design than younger SMEs, thus adding to the extant literature on the BM efficiency-firm performance relationship.

Furthermore, we extend the prior literature on the BM design-SME performance relationship by introducing environmental dynamism as an important moderating factor. Although the prior studies acknowledge the importance of the business environment, to the best of our knowledge they do not develop hypothesis and test the moderating impact of environmental dynamism on BM design - firm performance. We found environmental dynamism to positively moderate the BM novelty design-SME performance relationship, while it negatively moderates the BM efficiency design-SME performance relationship. This is an interesting finding on its own because it is directly related to a critical theoretical and practical question in the BM literature: how does the pace of environmental change influence the relationship between BM design and firm performance? Moreover, we found environmental munificence to negatively moderate the BM efficiency design-SME performance relationship but we found no significant moderating effect on BM novelty design and SME performance. One possible reason for this finding is that environments with low levels of munificence might encourage SMEs to creatively use the resources available to them and exploit the opportunities arising due to BM novelty. Prior studies on entrepreneurial bricolage (see Baker \& Nelson, 2005; Bradley et al., 2011) also support this argument. Therefore, in environments with both high and low levels of munificence, SMEs would 
benefit from BM novelty, highlighting no significant difference in the benefits of BM novelty across high and low levels of munificence. This finding is consistent with prior studies (Zott \& Amit, 2007), even though we used a self-rated measure to capture perception of environmental munificence whereas Zott and Amit (2007) used time period in their study.

As was pointed out, simultaneous deployment of different BM designs (parallel BMs) is attracting significant traction (e.g. Hacklin et al., 2017; Snihur \& Tarzijan, 2017). The theoretical arguments and empirical findings as to the benefits of simultaneously deploying multiple BM designs are patchy. In line with Zott and Amit (2007), we found that BM duality did not influence performance among our sample of SMEs operating in an emerging economy. But, critically and importantly, we found that mature SMEs benefit more than younger SMEs from BM dual design. Hence, the lack of contingency factors in the previous studies is a likely contributor to the inconsistency of empirical findings. Furthermore, our findings highlight the importance of considering contingent factors prior to deploying multiple BM designs.

To summarize, our study contributes to the extant literature by showing that the theory proposed by Zott and Amit (2007) largely holds true in an entirely new context moving a step closer to a general theory. We further develop our nascent understanding by demonstrating the importance of age and environmental dynamism in moderating the relationship between archetypal BM design and SME performance. This is important both from a theoretical and practical perspective.

\section{Practical Implications}

This study offers practical guidance to owner-managers of Indian SMEs. Although care should be taken when interpreting the coefficients, our findings suggest that owner-managers need to make careful choices when investing to improve their BM design for superior performance. Our findings 
suggest that all Indian SMEs benefit from BM novelty, thereby encouraging SMEs to invest in constantly improving their BM innovation. However, we caution owner-managers of younger SMEs to limit their investment in BM efficiency as it has limited benefits for younger SMEs. As our findings highlight, mature SMEs can benefit from operating BM novelty and BM efficiency side by side, but younger SMEs do not benefit from such BM dual design. Hence, we suggest that young SMEs in emerging economies avoid adding complexity in their BM and focus their resources towards improving only BM novelty. This would not only help them to improve their performance but also develop their competitive advantage over mature SMEs. In contrast, we suggest that owner-managers of mature SMEs carefully consider simultaneous deployment of multiple BM designs. However, mature SMEs should exercise caution to balance their efforts and resources on multiple BM designs by taking into consideration the external context.

Finally, we inform owner-managers regarding the impact of the external business environment on the relationship between their choice of BM design and SME performance. We suggest that SMEs operating in dynamic environments benefit from improving their BM novelty design and avoid excess commitment towards BM efficiency. We also suggest that SMEs that operate in environments with low levels of munificence ought to invest more in improving their BM efficiency design than SMEs operating in environments with high levels of munificence. Therefore, we encourage SMEs to carefully consider their internal and external conditions while making their decisions to improve BM design.

\section{Limitations and Future Research}

Despite our best efforts, this study has some limitations. Although cross-sectional data is intensively used in business and management research, they represent a point in time and might lead to CMV. We took steps to minimize CMV and our statistical tests suggest that it does not 
affect the robustness of our findings. Nevertheless, bias cannot be totally ruled out. Hence future researchers may consider using a longitudinal panel design and having multiple respondents for collecting data to better assess how BM novelty and BM efficiency designs influence firm performance over time. Our findings are limited by the firms whose owner-managers attended training programmes, a strategy commonly used in this type of research. Despite taking steps to minimize the common perspective resulting from the training programme, we cannot completely rule out certain data limitations as the respondents in effect were self-selected - choosing to attend a training programme and potentially holding a common perspective on learning, knowledge and resource investment. We drew our sample from among Indian SMEs and cannot assume complete generalization in the context of other economies or larger firms. Future researchers may consider replicating this study in other countries (emerging and developed) as well as within larger firms. Our study is helpful in highlighting the importance of BM novelty and BM efficiency designs, and the various conditions under which they are effective in improving firm performance. Future studies could add to these findings by identifying other firm-level and context-specific factors, such as organizational culture and commercialization of innovation, which might influence the relationship between BM design and firm performance.

\section{Conclusion}

To summarize, the main contribution of this study is to examine the moderating impact of a critical internal contingency (SME's age) and external contingencies (dynamism and munificence of the operating environment) on the relationship between archetypical BM design and SME performance in emerging economies. In doing so we provide additional empirical evidence in support of the influence of BM design on firm performance. Finally, we add to the BM dual design literature and highlight the conditions under which SMEs' performance is enhanced or hindered 
by simultaneously deploying dual novelty and efficiency BM designs. We hope these findings motivate future researchers to consider BM as an important construct and enable further research to enhance our knowledge regarding BMs, the various factors that help firms to enhance them and their implications for firms and society.

\section{REFERENCES}

Ahlstrom, D., Bruton, G. D., 2006. Venture capital in emerging economies: Networks and institutional change. Entrepreneurship Theory and Practice, 30(2), 299-320.

Amit, R., Zott, C., 2001. Value creation in e-business. Strategic Management Journal, 22(6-7), 493-520.

Andries, P., Debackere, K., 2007. Adaptation and performance in new businesses: Understanding the moderating effects of independence and industry. Small Business Economics, 29(12), 81-99.

Antonakis, J., Bendahan, S., Jacquart, P., Lalive, R., 2010. On making causal claims: A review and recommendations. The Leadership Quarterly, 21(6), 1086-1120.

Aragon-Correa, J. A., Sharma, S., 2003. A contingent resource-based view of proactive corporate environmental strategy. Academy of Management Review, 28(1), 71-88.

Aspara, J., Hietanen, J., Tikkanen, H., 2010. Business model innovation vs replication: financial performance implications of strategic emphases. Journal of Strategic Marketing, 18(1), 39-56.

Autio, E., Sapienza, H. J., Almeida, J. G., 2000. Effects of age at entry, knowledge intensity, and imitability on international growth. Academy of management journal, 43(5), 909-924.

Ayyagari, M., Beck, T., Demirguc-Kunt, A., 2007. Small and medium enterprises across the globe. Small Business Economics, 29(4), 415-434.

Baden-Fuller, C., Haefliger, S., 2013. Business Models and Technological Innovation. Long Range Planning, 46(6), 419-426.

Baker, T., Nelson, R. E., 2005. Creating something from nothing: Resource construction through entrepreneurial bricolage. Administrative science quarterly, 50(3), 329-366.

Battistella, C., De Toni, A. F., De Zan, G., Pessot, E., 2017. Cultivating business model agility through focused capabilities: A multiple case study. Journal of Business Research, 73, 65-82.

Bettis, R. A., Ethiraj, S., Gambardella, A., Helfat, C., Mitchell, W., 2016. Creating repeatable cumulative knowledge in strategic management. Strategic Management Journal, 37(2), 257-261.

Bliese, P. D., 1998. Group size, ICC values, and group-level correlations: A simulation. Organizational Research Methods, 1(4), 355-373.

Bono, J. E., McNamara, G., 2011. Publishing in AMJ—part 2: Research design. Academy of Management Journal, 54(4), 657-660.

Bradley, S. W., Shepherd, D. A., Wiklund, J., 2011. The importance of slack for new organizations facing 'tough'environments. Journal of Management Studies, 48(5), 10711097. 
Brettel, M., Strese, S., Flatten, T. C., 2012. Improving the performance of business models with relationship marketing efforts-An entrepreneurial perspective. European Management Journal, 30(2), 85-98.

Brouthers, K. D., Brouthers, L. E., Werner, S., 1996. Dunning's eclectic theory and the smaller firm: the impact of ownership and locational advantages on the choice of entry-modes in the computer software industry. International Business Review, 5(4), 377-394.

Carr, J. C., Haggard, K. S., Hmieleski, K. M., Zahra, S. A., 2010. A study of the moderating effects of firm age at internationalization on firm survival and short-term growth. Strategic Entrepreneurship Journal, 4(2), 183-192.

Casadesus-Masanell, R., Ricart, J. E., 2011. How to design a winning business model. Harvard Business Review, 89(1/2), 100-107.

Casadesus-Masanell, R., Tarzijan, J., 2012. When One Business Model Isn't Enough LAN Airlines flourishes by running three distinctly different operations at the same time. Harvard Business Review, 90(1-2), 132-138.

Casadesus-Masanell, R., Zhu, F., 2013. Business Model Innovation and Competitive Imitation: the case of sponsor-based business models. Strategic Management Journal, 34(4), 464482.

Castrogiovanni, G. J., 1991. Environmental Munihcence; A Theoretical Assessment. Academy of management review, 16(3), 542-565.

Chesbrough, H., 2010. Business model innovation: opportunities and barriers. Long Range Planning, 43(2), 354-363.

Cohen, J., Cohen, P., West, S. G., Aiken, L. S., 2013. Applied multiple regression/correlation analysis for the behavioral sciences, Routledge.

Covin, J. G., Slevin, D. P., 1989. Strategic management of small firms in hostile and benign environments. Strategic Management Journal, 10(1), 75-87.

Craighead, C. W., Ketchen, D. J., Dunn, K. S., Hult, G. T. M., 2011. Addressing common method variance: guidelines for survey research on information technology, operations, and supply chain management. IEEE Transactions on Engineering Management, 58(3), 578-588.

Cucculelli, M., Bettinelli, C., 2015. Business models, intangibles and firm performance: evidence on corporate entrepreneurship from Italian manufacturing SMEs. Small Business Economics, 45(2), 329-350.

Dahan, N. M., Doh, J. P., Oetzel, J., Yaziji, M., 2010. Corporate-NGO collaboration: Co-creating new business models for developing markets. Long Range Planning, 43(2), 326-342.

DaSilva, C. M., Trkman, P., 2014. Business Model: What It Is and What It Is Not. Long Range Planning, 47(6), 379-389.

Demil, B., Lecocq, X., 2010. Business model evolution: in search of dynamic consistency. Long Range Planning, 43(2), 227-246.

Deschryvere, M., 2014. R\&D, firm growth and the role of innovation persistence: an analysis of Finnish SMEs and large firms. Small Business Economics, 43(4), 767-785.

Dess, G. G., Beard, D. W., 1984. Dimensions of organizational task environments. Administrative Science Quarterly, 29(1), 52-73.

Dunford, R., Palmer, I., Benveniste, J., 2010. Business model replication for early and rapid internationalisation: The ING direct experience. Long Range Planning, 43(5), 655-674. 
Ensley, M. D., Pearce, C. L., Hmieleski, K. M., 2006. The moderating effect of environmental dynamism on the relationship between entrepreneur leadership behavior and new venture performance. Journal of Business Venturing, 21(2), 243-263.

Foss, N. J., Saebi, T., 2017. Fifteen years of research on business model innovation: How far have we come, and where should we go? Journal of Management, 43(1), 200-227.

George, G., Bock, A. J., 2011. The business model in practice and its implications for entrepreneurship research. Entrepreneurship Theory and Practice, 35(1), 83-111.

Gersick, C. J. G., 1991. Revolutionary change theories: A multilevel exploration of the punctuated equilibrium paradigm. Academy of Management Review, 16(1), 10-36.

Ghemawat, P., 2003. The forgotten strategy, Harvard Business Online.

Goll, I., Rasheed, A. A., 2004. The moderating effect of environmental munificence and dynamism on the relationship between discretionary social responsibility and firm performance. Journal of Business Ethics, 49(1), 41-54.

Green, K. M., Covin, J. G., Slevin, D. P., 2008. Exploring the relationship between strategic reactiveness and entrepreneurial orientation: The role of structure-style fit. Journal of Business Venturing, 23(3), 356-383.

Gronum, S., Steen, J., Verreynne, M.-L., 2016. Business model design and innovation: Unlocking the performance benefits of innovation. Australian Journal of Management, 41(3), 585-605.

Gupta, V. K., Batra, S., 2016. Entrepreneurial orientation and firm performance in Indian SMEs: Universal and contingency perspectives. International Small Business Journal, 34(5), 660-682.

Habib, M. M., Victor, B., 2006. Strategy, structure, and performance of US manufacturing and service MNCs: A comparative analysis. Strategic Management Journal, 12(8), 589-606.

Hacklin, F., Björkdahl, J., Wallin, M. W., 2017. Strategies for business model innovation: How firms reel in migrating value. Long Range Planning.

Harman, H. H., 1976. Modern factor analysis, University of Chicago Press, Chicago, IL.

Hart, S., Prahalad, C., 2002. The Fortune at the Bottom of the Pyramid. Strategy+ Business, 26, 54-67.

Husted, B. W., Allen, D. B., 2007. Strategic corporate social responsibility and value creation among large firms: lessons from the Spanish experience. Long range planning, 40(6), 594-610.

Javalgi, R. R. G., Todd, P. R., 2011. Entrepreneurial orientation, management commitment, and human capital: the internationalization of SMEs in India. Journal of Business Research, 64(9), 1004-1010.

Johnson, M. W., Christensen, C. M., Kagermann, H., 2008. Reinventing your business model. Harvard business review, 86(12), 57-68.

Johnson, S. E., Hall, A., 2005. The prediction of safe lifting behavior: An application of the theory of planned behavior. Journal of Safety Research, 36(1), 63-73.

Kale, P., Banwait, S., Laroiya, S., 2010. Performance evaluation of ERP implementation in Indian SMEs. Journal of Manufacturing Technology Management, 21(6), 758-780.

Karimi, J., Walter, Z., 2016. Corporate entrepreneurship, disruptive business model innovation adoption, and its performance: The case of the newspaper industry. Long Range Planning, 49(3), 342-360.

Kim, S. K., Min, S., 2015. Business model innovation performance: When does adding a new business model benefit an incumbent? Strategic Entrepreneurship Journal, 9(1), 34-57. 
Kim, W. C., Mauborgne, R., 2005. Blue ocean strategy: How to create uncontested market space and make competition irrelevant, Harvard Business Press, Boston, MA.

Kotha, R., Zheng, Y., George, G., 2011. Entry into new niches: the effects of firm age and the expansion of technological capabilities on innovative output and impact. Strategic Management Journal, 32(9), 1011-1024.

Krishnaswamy, K., Mathirajan, M., Subrahmanya, M. B., 2014. Technological innovations and its influence on the growth of auto component SMEs of Bangalore: A case study approach. Technology in Society, 38, 18-31.

Kulins, C., Leonardy, H., Weber, C., 2016. A configurational approach in business model design. Journal of Business Research, 69(4), 1437-1441.

Landis, R. S., Dunlap, W. P., 2000. Moderated multiple regression tests are criterion specific. Organizational Research Methods, 3(3), 254-266.

Langlois, R. N., Robertson, P. L., 1995. Firms, markets and economic change: a dynamic theory of business institutions, Routledge, London, UK.

Lavie, D., Kang, J., Rosenkopf, L., 2011. Balance within and across domains: The performance implications of exploration and exploitation in alliances. Organization Science, 22(6), 1517-1538.

Lepak, D. P., Smith, K. G., Taylor, M. S., 2007. Value creation and value capture: A multilevel perspective. Academy of Management Review, 32(1), 180-194.

Li, D.-y., Liu, J., 2014. Dynamic capabilities, environmental dynamism, and competitive advantage: Evidence from China. Journal of Business Research, 67(1), 2793-2799.

Li, M., Simerly, R. L., 1998. The moderating effect of environmental dynamism on the ownership and performance relationship. Strategic Management Journal, 19(2), 169-179.

Lindell, M. K., Whitney, D. J., 2001. Accounting for common method variance in cross-sectional research designs. Journal of applied psychology, 86(1), 114.

London, T., Hart, S. L., 2004. Reinventing strategies for emerging markets: beyond the transnational model. Journal of International Business Studies, 35(5), 350-370.

Lukács, E., 2005. The economic role of SMEs in world economy, especially in Europe. European Integration Studies, 1(4), 3-12.

Lumpkin, G. T., Dess, G. G., 2001. Linking two dimensions of entrepreneurial orientation to firm performance: The moderating role of environment and industry life cycle. Journal of Business Venturing, 16(5), 429-451.

MacKenzie, S. B., Podsakoff, P. M., 2012. Common method bias in marketing: causes, mechanisms, and procedural remedies. Journal of Retailing, 88(4), 542-555.

Markides, C. C., 2013. Business model innovation: What can the ambidexterity literature teach us? The Academy of Management Perspectives, 27(4), 313-323.

McNamara, P., Peck, S. I., Sasson, A., 2013. Competing Business Models, Value Creation and Appropriation in English Football. Long Range Planning, 46(6), 475-487.

Mezger, F., 2014. Toward a capability-based conceptualization of business model innovation: insights from an explorative study. R\&D Management, 44(5), 429-449.

Miller, D., Friesen, P. H., 1982. Structural change and performance: Quantum versus piecemealincremental approaches. Academy of Management Journal, 25(4), 867-892.

Miller, K. D., 2007. Risk and rationality in entrepreneurial processes. Strategic Entrepreneurship Journal, 1(1-2), 57-74.

Mistry, J. J., 2005. Origins of profitability through JIT processes in the supply chain. Industrial Management \& Data Systems, 105(6), 752-768. 
Mohr, J., Spekman, R., 2006. Characteristics of partnership success: partnership attributes, communication behavior, and conflict resolution techniques. Strategic Management Journal, 15(2), 135-152.

Nandakumar, M., Ghobadian, A., O'Regan, N., 2010. Business-level strategy and performance: The moderating effects of environment and structure. Management Decision, 48(6), 907939.

Nelson, R. R., Winter, S. G., 1982. The Schumpeterian tradeoff revisited. The American Economic Review, 72(1), 114-132.

O'Regan, N., Ghobadian, A., 2004. Testing the homogeneity of SMEs: The impact of size on managerial and organisational processes. European Business Review, 16(1), 64-77.

Palmisano, S. 2006. Expanding the innovation horizon: the global CEO study 2006, Report, IBM Global Business Services, Somers, NY.

Pati, R. K., Garud, N., 2011. SELCO: lighting rural India. Emerald Emerging Markets Case Studies, 1(3), 1-19.

Podsakoff, P. M., MacKenzie, S. B., Lee, J. Y., Podsakoff, N. P., 2003. Common method biases in behavioral research: a critical review of the literature and recommended remedies. Journal of Applied Psychology, 88(5), 879.

Prahalad, C. K., 2006. The fortune at the bottom of the pyramid: Eradicating poverty through profits, Wharton School Publishing, Upper Saddle River, NJ.

Puffer, S. M., McCarthy, D. J., Boisot, M., 2010. Entrepreneurship in Russia and China: The impact of formal institutional voids. Entrepreneurship theory and practice, 34(3), 441467.

Ramanujam, V., Venkatraman, N., 1987. Planning system characteristics and planning effectiveness. Strategic Management Journal, 8(5), 453-468.

Read, S., Song, M., Smit, W., 2009. A meta-analytic review of effectuation and venture performance. Journal of business venturing, 24(6), 573-587.

Rosenbusch, N., Brinckmann, J., Bausch, A., 2011. Is innovation always beneficial? A metaanalysis of the relationship between innovation and performance in SMEs. Journal of Business Venturing, 26(4), 441-457.

Sabatier, V., Mangematin, V., Rousselle, T., 2010. From recipe to dinner: business model portfolios in the European biopharmaceutical industry. Long Range Planning, 43(2), 431447.

Sanchez, P., Ricart, J. E., 2010. Business model innovation and sources of value creation in lowincome markets. European management review, 7(3), 138-154.

Sapienza, H. J., Autio, E., George, G., Zahra, S. A., 2006. A capabilities perspective on the effects of early internationalization on firm survival and growth. Academy of Management Review, 31(4), 914-933.

Schneider, S., Spieth, P., 2013. Business model innovation: Towards an integrated future research agenda. International Journal of Innovation Management, 17(01), 1340001.

Shrader, C. B., Taylor, L., Dalton, D. R., 1984. Strategic planning and organizational performance: A critical appraisal. Journal of Management, 10(2), 149-171.

Siqueira, A. C. O., Webb, J. W., Bruton, G. D., 2016. Informal entrepreneurship and industry conditions. Entrepreneurship Theory and Practice, 40(1), 177-200.

Sirmon, D. G., Hitt, M. A., Ireland, R. D., 2007. Managing firm resources in dynamic environments to create value: Looking inside the black box. Academy of management review, 32(1), 273-292. 
Slevin, D. P., Covin, J. G., 1997. Strategy formation patterns, performance, and the significance of context. Journal of Management, 23(2), 189-209.

Snihur, Y., Tarzijan, J., 2017. Managing complexity in a multi-business-model organization. Long Range Planning.

Sosna, M., Trevinyo-Rodríguez, R. N., Velamuri, S. R., 2010. Business model innovation through trial-and-error learning: The Naturhouse case. Long Range Planning, 43(2), 383407.

Sull, D., 2009. How to thrive in turbulent markets. Harvard Business Review, 87(2).

Tabachnick, B. G., Fidell, L., 2012. Using Multivariate Statistics: International Edition, Pearson.

Teece, D. J., 2010. Business models, business strategy and innovation. Long Range Planning, 43(2), 172-194.

Terziovski, M., 2010. Innovation practice and its performance implications in small and medium enterprises (SMEs) in the manufacturing sector: a resource-based view. Strategic Management Journal, 31(8), 892-902.

Thornhill, S., Amit, R., 2003. Learning about failure: bankruptcy, firm age, and the resourcebased view. Organization Science, 14(5), 497-509.

Velu, C., 2015. Business model innovation and third-party alliance on the survival of new firms. Technovation, 35, 1-11.

Velu, C., Jacob, A., 2016. Business model innovation and owner-managers: the moderating role of competition. R\&D Management, 46(3), 451-463.

Velu, C., Stiles, P., 2013. Managing Decision-Making and Cannibalization for Parallel Business Models. Long Range Planning, 46(6), 443-458.

Volberda, H. W., 1996. Toward the flexible form: How to remain vital in hypercompetitive environments. Organization science, 7(4), 359-374.

Wei, Z., Yang, D., Sun, B., Gu, M., 2014. The fit between technological innovation and business model design for firm growth: evidence from China. R\&D Management, 44(3), 288-305.

Weill, P., Malone, T. W., Apel, T. G., 2011. The business models investors prefer. MIT Sloan Management Review, 52(4), 17.

Wernerfelt, B., Karnani, A., 2006. Competitive strategy under uncertainty. Strategic Management Journal, 8(2), 187-194.

Williams, L. J., Hartman, N., Cavazotte, F., 2010. Method variance and marker variables: A review and comprehensive CFA marker technique. Organizational Research Methods, 13(3), 477-514.

Winter, S. G., Szulanski, G., 2001. Replication as strategy. Organization Science, 12(6), 730743.

Winterhalter, S., Zeschky, M. B., Gassmann, O., 2016. Managing dual business models in emerging markets: an ambidexterity perspective. R\&D Management, 46(3), 464-479.

Wirtz, B. W., Pistoia, A., Ullrich, S., Göttel, V., 2016. Business models: Origin, development and future research perspectives. Long Range Planning, 49(1), 36-54.

Yli-Renko, H., Autio, E., Sapienza, H. J., 2001. Social capital, knowledge acquisition, and knowledge exploitation in young technology-based firms. Strategic Management Journal, 22(6-7), 587-613.

Zaheer, A., Bell, G. G., 2005. Benefiting from network position: firm capabilities, structural holes, and performance. Strategic Management Journal, 26(9), 809-825. 
Zahra, S. A., Covin, J. G., 1995. Contextual influences on the corporate entrepreneurshipperformance relationship: A longitudinal analysis. Journal of Business Venturing, 10(1), 43-58.

Zahra, S. A., Filatotchev, I., 2004. Governance of the Entrepreneurial Threshold Firm: A Knowledge-based Perspective. Journal of Management Studies, 41(5), 885-897.

Zahra, S. A., George, G., 2002. Absorptive capacity: A review, reconceptualization, and extension. Academy of Management Review, 27(2), 185-203.

Zahra, S. A., Ireland, R. D., Hitt, M. A., 2000. International expansion by new venture firms: International diversity, mode of market entry, technological learning, and performance. Academy of Management Journal, 43(5), 925-950.

Zhou, K. Z., Wu, F., 2009. Technological capability, strategic flexibility, and product innovation. Strategic Management Journal, 31(5), 547-561.

Zook, C., Allen, J., 2003. Growth outside the core. Harvard Business Review, 81(12), 66-75.

Zook, C., Allen, J., 2011. The Great Repeatable Business Model. Harvard Business Review.

Zott, C., Amit, R., 2007. Business model design and the performance of entrepreneurial firms. Organization Science, 18(2), 181-199.

Zott, C., Amit, R., 2008. The fit between product market strategy and business model: implications for firm performance. Strategic Management Journal, 29(1), 1-26.

Zott, C., Amit, R., 2010. Business model design: an activity system perspective. Long Range Planning, 43(2), 216-226.

Zott, C., Amit, R., 2013. The business model: A theoretically anchored robust construct for strategic analysis. Strategic Organization, 11(4), 403-411.

Zott, C., Amit, R., Massa, L., 2011. The business model: Recent developments and future research. Journal of Management, 37(4), 1019-1042. 


\section{TABLES}

Table 1. Descriptive Statistics and Correlations

\begin{tabular}{|l|l|l|l|l|l|l|l|l|l|l|l|}
\hline & & Mean & SD & 1 & 2 & 3 & 4 & 5 & 6 & 7 & 8 \\
\hline 1 & BM novelty & 4.37 & 0.99 & 1 & & & & & & & \\
\hline 2 & BM efficiency & 4.43 & 0.96 & $0.17^{* *}$ & 1 & & & & & & \\
\hline 3 & Performance & 4.60 & 0.95 & $0.32^{* *}$ & $0.20^{* *}$ & 1 & & & & & \\
\hline 4 & Munificence & 4.54 & 1.13 & -0.08 & -0.05 & 0.01 & 1 & & & & \\
\hline 5 & Dynamism & 3.51 & 1.11 & 0.11 & -0.04 & -0.07 & $-0.15^{*}$ & 1 & & & \\
\hline 6 & Firm age & 0.64 & 0.48 & $-0.19^{* *}$ & $0.26^{* *}$ & 0.07 & $0.17^{* *}$ & $-0.19^{* *}$ & 1 & & \\
\hline 7 & International office & 0.17 & 0.37 & 0.06 & $0.19^{* *}$ & 0.11 & 0.02 & -0.05 & 0.01 & 1 & \\
\hline 8 & Industry sector & 0.60 & 0.49 & 0.06 & $0.16^{*}$ & -0.01 & 0.02 & 0.02 & -0.01 & $0.14^{*}$ & 1 \\
\hline 9 & Firm size & 1.34 & 0.86 & 0.08 & $0.25^{* *}$ & $0.27^{* *}$ & 0.04 & -0.03 & -0.01 & $0.17^{* *}$ & $0.13^{*}$ \\
\hline
\end{tabular}

Notes: $* *=$ statistically significant at $1 \% ; *=$ statistically significant at $5 \%$.

Table 2. Results of the OLS Regression Analysis for Firm Performance $(\mathrm{N}=241)$

\begin{tabular}{|c|c|c|c|c|c|c|}
\hline & Model 1 & Model2 & Model 3 & Model 4 & Model 5 & Model 6 \\
\hline Firm size & $0.265 * * *$ & $0.23 * * *$ & $0.225 * * *$ & $0.231 * * *$ & $0.216 * * *$ & $0.206 * * *$ \\
\hline International office & 0.067 & 0.04 & 0.044 & 0.078 & 0.081 & 0.086 \\
\hline Industry sector & -0.050 & -0.071 & -0.07 & $-0.119 *$ & $-0.111^{*}$ & $-0.112 *$ \\
\hline Firm age & & 0.094 & 0.097 & $0.151 *$ & 0.109 & 0.103 \\
\hline Dynamism & & -0.069 & -0.071 & -0.078 & -0.082 & -0.076 \\
\hline Munificence & & 0.006 & 0.007 & 0.036 & 0.025 & 0.027 \\
\hline BM novelty & & $0.314 * * *$ & $0.304 * * *$ & $0.496 * * *$ & $0.357 * *$ & $0.303^{*}$ \\
\hline BM efficiency & & 0.067 & 0.063 & $-0.39 * * *$ & $-0.345^{* * *}$ & $-0.286^{* *}$ \\
\hline BM novelty $\times$ BM efficiency & & & -0.046 & 0.054 & -0.179 & -0.159 \\
\hline BM novelty $\times$ Firm age & & & & $-0.25 *$ & -0.136 & -0.068 \\
\hline BM efficiency $\times$ Firm age & & & & $0.601 * * *$ & $0.586 * * *$ & $0.524 * * *$ \\
\hline $\begin{array}{l}\text { BM novelty } \times \text { BM efficiency } \\
\times \text { Firm age }\end{array}$ & & & & & $0.257 *$ & $0.245^{*}$ \\
\hline BM novelty $\times$ Dynamism & & & & & & $0.131 *$ \\
\hline BM novelty $\times$ Munificence & & & & & & 0.066 \\
\hline BM efficiency $\times$ Dynamism & & & & & & $-0.121 *$ \\
\hline BM efficiency $\times$ Munificence & & & & & & $-0.119 *$ \\
\hline $\mathrm{R}^{2}$ & 0.079 & 0.19 & 0.192 & 0.322 & 0.337 & 0.381 \\
\hline Adjusted $\mathrm{R}^{2}$ & 0.067 & 0.162 & 0.161 & 0.289 & 0.302 & 0.337 \\
\hline $\mathrm{F}$ & $6.738 * *$ & $6.804 * * *$ & $6.099 * * *$ & $9.869 * * *$ & $9.659 * * *$ & $8.619 * * *$ \\
\hline F change & $6.738 * *$ & $6.385^{* * *}$ & 0.56 & $21.87 * * *$ & $5.313 *$ & $3.982 * *$ \\
\hline
\end{tabular}

Notes: Standardized coefficients are reported; $*$ statistically significant at 5\%;

$* *=$ statistically significant at $1 \% ; * * *=$ statistically significant at $0.1 \%$. 
Table 3. Correlation Results Between Business Model Designs and ROA

\begin{tabular}{|l|l|l|l|l|l|l|l|}
\hline & $\begin{array}{l}\text { All } \\
\text { firms }\end{array}$ & $\begin{array}{l}\text { Young } \\
\text { firms }\end{array}$ & $\begin{array}{l}\text { Mature } \\
\text { firms }\end{array}$ & $\begin{array}{l}\text { Low } \\
\text { dynamism }\end{array}$ & $\begin{array}{l}\text { High } \\
\text { dynamism }\end{array}$ & $\begin{array}{l}\text { Low } \\
\text { munificence }\end{array}$ & $\begin{array}{l}\text { High } \\
\text { munificence }\end{array}$ \\
\hline BM novelty & $0.620^{* *}$ & $0.699^{* *}$ & $0.535^{* *}$ & $0.561^{* *}$ & $0.709^{* *}$ & $0.612^{* *}$ & $0.613^{* *}$ \\
\hline BM efficiency & $0.420^{* *}$ & 0.023 & $0.686^{* *}$ & $0.547^{* *}$ & 0.293 & $0.563 * *$ & 0.165 \\
\hline $\begin{array}{l}\text { BM novelty } \mathrm{x} \\
\text { BM efficiency }\end{array}$ & -0.196 & $-0.494^{*}$ & -0.129 & & & & \\
\hline $\mathrm{N}$ & 66 & 24 & 40 & 33 & 31 & 35 & 29 \\
\hline
\end{tabular}

Notes: $*=$ statistically significant at $5 \% ; * *=$ statistically significant at $1 \%$

Table 4. Results Obtained by Testing the Hypotheses

\begin{tabular}{|l|l|}
\hline Hypothesis & Result \\
\hline $\begin{array}{l}\text { H1a: Business model novelty design has a positive effect on performance of SMEs in } \\
\text { emerging economies }\end{array}$ & Supported \\
\hline $\begin{array}{l}\text { H1b: Business model efficiency design has a positive effect on performance of SMEs } \\
\text { in emerging economies }\end{array}$ & Not supported \\
\hline $\begin{array}{l}\text { H1c: Business model dual design is positively associated with performance of SMEs in } \\
\text { emerging economies }\end{array}$ & Not supported \\
\hline $\begin{array}{l}\text { H2a: Business model novelty design has a higher positive effect on the performance of } \\
\text { younger SMEs than on mature SMEs in emerging economies }\end{array}$ & Supported \\
\hline $\begin{array}{l}\text { H2b: Business model efficiency design has a higher positive effect on the performance } \\
\text { of mature SMEs than on younger SMEs in emerging economies }\end{array}$ & Supported \\
\hline $\begin{array}{l}\text { H2c: Business model dual design has a higher positive effect on the performance of } \\
\text { mature SMEs than on younger SMEs in emerging economies }\end{array}$ & Supported \\
\hline $\begin{array}{l}\text { H3a: Business model novelty design has a higher positive effect on the performance of } \\
\text { SMEs operating in environments with high levels of dynamism compared to those } \\
\text { operating in environments with low levels of dynamism in emerging economies }\end{array}$ & Supported \\
\hline $\begin{array}{l}\text { H3b: Business model novelty design has a higher positive effect on performance of } \\
\text { SMEs operating in environments with high levels of munificence compared to those } \\
\text { operating in environments with low levels of munificence in emerging economies }\end{array}$ & Not supported \\
\hline $\begin{array}{l}\text { H3c: Business model efficiency design has a higher positive effect on the performance } \\
\text { of SMEs operating in environments with low levels of dynamism compared to those } \\
\text { operating in environments with high levels of dynamism in emerging economies }\end{array}$ & Supported \\
\hline $\begin{array}{l}\text { H3d: Business model efficiency design has a higher positive effect on the performance } \\
\text { of SMEs operating in environments with low levels of munificence compared to those } \\
\text { operating in environments with high levels of munificence in emerging economies }\end{array}$ & Supported \\
\hline
\end{tabular}




\section{Appendix I. Final Items of the Scales Used in the Study}

\begin{tabular}{|l|l|}
\hline \multicolumn{2}{|l|}{ Business model novelty } \\
\hline & Our BM offers novel incentives to the stakeholders in the transactions \\
\hline & Our BM offers new combinations of products, services and information \\
\hline & Our BM brings together new stakeholders (previously unconnected parties) \\
\hline & Our BM links stakeholders to transactions in novel ways \\
\hline & $\begin{array}{l}\text { Our BM increases the richness (i.e. quality and depth) of some of the links between } \\
\text { participants }\end{array}$ \\
\hline & Our BM creates novel value by challenging existing business models \\
\hline & Our BM creates and captures value in a way that no other firm does \\
\hline \multicolumn{1}{|c|}{ Business model efficiency } \\
\hline & Our BM makes the transactions simple (ease of transaction) for all stakeholders \\
\hline & Our BM enables a low number of errors in the execution of transactions \\
\hline & Our BM is scalable (i.e. can handle a small and a large number of transactions) \\
\hline & Our BM enables stakeholders to make informed decisions \\
\hline & Our BM makes the transactions transparent \\
\hline & $\begin{array}{l}\text { As part of transactions, information is provided to stakeholders to reduce an asymmetric } \\
\text { degree of knowledge among them regarding the quality and nature of the goods being } \\
\text { exchanged }\end{array}$ \\
\hline Information is provided to stakeholders about each other \\
\hline & $\begin{array}{l}\text { Access to a large range of products, services, information and other stakeholders is } \\
\text { provided }\end{array}$ \\
\hline & Our BM enables fast transactions \\
\hline Environmental dynamism (reverse coded) \\
\hline & Actions of competitors are generally quite easy to predict \\
\hline & $\begin{array}{l}\text { The set of competitors in my industry has remained relatively constant over the last three } \\
\text { years }\end{array}$ \\
\hline & Product demand is easy to forecast \\
\hline & Customer requirements/preferences are easy to forecast \\
\hline & $\begin{array}{l}\text { My industry is very stable with very little change resulting from major economic, } \\
\text { technological, social or political forces }\end{array}$ \\
\hline Environmental munificence (reverse coded) \\
\hline & Competitive intensity is high in my industry \\
\hline Customer loyalty is low in my industry \\
\hline & Severe price wars are characteristic of my industry \\
\hline Low profit margins are characteristic of my industry \\
\hline Firm performance \\
\hline & Revenue \\
\hline Profit \\
\hline & Sales growth \\
\hline & Growth of profit after tax \\
\hline & Market share \\
\hline & Competitive position \\
\hline & Overall performance \\
\hline
\end{tabular}

